\title{
Trade is central to achieving the sustainable development goals: a case study of antimicrobial resistance
}

\author{
(c) (1) (8) OPEN ACCESS
}

Johanna Hanefeld and colleagues highlight the links between trade and health and argue for greater consideration of trade agreements in actions to meet the sustainable development goals

\author{
Johanna Hanefeld associate professor, health policy and systems ${ }^{1}$, Mishal Khan assistant professor \\ health policy and systems research ${ }^{1}$, Göran Tomson senior professor global health ${ }^{2}{ }^{3}$, Richard \\ Smith professor of health economics and systems ${ }^{1}$
}

${ }^{1}$ Faculty of Public Health and Policy, London School of Hygiene and Tropical Medicine London, London, UK; ${ }^{2}$ Public Health—Global Health/IHCAR, Karolinska Institutet, Stockholm, Sweden; ${ }^{3}$ Swedish Institute for Global Health Transformation (SIGHT), Stockholm

The 17 sustainable development goals adopted by 198 nations in September 2015 provide a transformative framework for global action across a wide range of areas. Health is an essential component of many of the goals, such as those relating to hunger, the environment, and education. The third goal (SDG3) focuses explicitly on health: "Ensure healthy lives and promote well-being for all at all ages."

Like health, trade is explicitly targeted in several of the goals. However, it is also a critical determinant of other goals where it has not been mentioned. We discuss the often overlooked centrality of trade as a determinant of health through a case study of antimicrobial resistance. ${ }^{2}$ Although not explicitly mentioned in the sustainable development goals, antimicrobial resistance threatens health, prosperity, and sustainable development. ${ }^{3}$ It is responsible for an estimated 700000 deaths annually, forecast to be 10 million by $2050 .^{3}$

\section{Trade and health}

The link between trade (agreements) and health (systems) has been well documented over the past decade. ${ }^{4-8}$ The interaction can be considered in four parts:

Commodities traded-This may be commodities harmful to health, such as tobacco and alcohol, ${ }^{9}{ }^{10}$ or those which may be beneficial, such as fresh fruit and vegetables. ${ }^{11-13}$

Trade agreements and the provisions-The legal framework provided for which goods can cross borders. Here the initial focus was on access to medicines and intellectual property (and this connection is explicitly acknowledged in SDG3 (target 3B), mainly through the Agreement on Trade Related Aspects of Intellectual Property Rights (TRIPS) ${ }^{14-16}$ Over the past five years the focus has been increasingly on regional and bilateral trade agreements, often related to non-communicable diseases and their risk factors. ${ }^{17-20}$

Trade in services ${ }^{21}$-This includes the movement of health workers, telemedicine, medical tourism, and foreign direct investment in health systems. ${ }^{22-24}$

Wider determinants of trade on health-These are both positive and negative, ${ }^{25}$ including patterns of employment, urbanisation, income, and housing, with considerable evidence to suggest trade as determinant of health inequities. ${ }^{827}$

\section{Trade and antimicrobial resistance}

Antimicrobial resistance has rapidly ascended the political agenda and is now recognised as a major threat to health, prosperity, and global health security. ${ }^{28}$ Substantial funding - with estimates of $\$ 40 \mathrm{bn}$ ( $£ 31 \mathrm{bn}$; $€ 35 \mathrm{bn}$ ) over the next 10 years-is being sought to tackle the problem, and the World Health Assembly endorsed a global action plan on antimicrobial resistance in 2015. ${ }^{28}$ But meeting these challenges will not be straightforward as it requires the collaboration of a large number of stakeholders across animal, human, and environmental spheres, often with conflicting interests and networks. ${ }^{29}$

Here we outline core areas where trade is critical to tackling antimicrobial resistance, highlighting key areas for action to achieve the SDGs and the 2030 agenda (box 1). We will focus 
mainly on commodities traded and the possible effect of trade related regulation and agreements.

Trade and antimicrobial resistance intersect in several ways. On a fundamental level trade (mobility) of people, animals, and goods is connected to the spread of microbes, and in human transmission there is a clear association with travel routes and the emergence of antimicrobial resistance. ${ }^{50}$

\section{Commodities}

\section{Trade in food products that contain resistant bacteria}

The most important sector in terms of trade relating to antimicrobial resistance is in livestock, food animals, and their feed, particularly in animals that host resistant bacteria. For example, the global trade in meat is large: the United States Department of Agriculture predicted that global production of beef and veal would rise to 62 million tonnes in 2017, with global exports predicted to be 9.6 million tonnes. Export of broiler chicken meat was expected to be a record 11.2 million tonnes. ${ }^{37}$

Drug resistant Escherichia coli can live on beef carcasses even after 24 hours in a chiller and in minced beef that has been stored for up to eight days. ${ }^{38} \mathrm{~A}$ study of raw meat samples provided by retail traders in the Netherlands found meticillin resistant Staphylococcus aureus (MRSA) in many of the samples, ranging from $35.3 \%$ of turkey samples to $2.2 \%$ of game samples ${ }^{39}$ While many low and middle income countries export food products and animals, their capacity to monitor antimicrobial resistance adequately may be limited by overall budget constraints. ${ }^{35} 40$

Trade is a possible route for spreading resistance. One response, where animals are tested for resistant strains as part of efforts to control the spread of antimicrobial resistance, is likely to affect trade immediately as animals with positive results would be banned. A challenge here is that although many farmers are advised to vaccinate their animals, it is hard to enforce and to differentiate between livestock vaccinated and those infected. Vaccination is also not currently routine in all countries. Thus, national strategies to contain antimicrobial resistance through vaccination may clash with global antimicrobial resistance control and prevent farmers from trading their animals across national borders.

\section{Availability of antimicrobials}

Trade in antimicrobials also affects their availability for human and animal consumption. Part of the complexity of addressing antimicrobial resistance is balancing access to medicines against overconsumption; at the global level the consensus is that we are probably consuming too many antimicrobials, but many of the worlds' poorest people still lack access to the essential medicines they need. More than a million children die each year from sepsis and untreated infection, ${ }^{31}$ which is inconsistent with target 8 of SDG3: "Achieving universal health coverage including access to safe, effective, quality, and affordable essential medicines for all."

Clearly, efforts to tackle antimicrobial resistance have to acknowledge that appropriate access is part of a wider global trading system, which links incentives and profits from medicines to volume of sales. Access to good quality antimicrobials is determined by intellectual property provisions set out as part of trade agreements, which set availability and price within a country, as well as regulations concerning safety and substandard medicines, relying on local action and enforcement.
These intellectual property provisions are either insufficient or insufficiently implemented to ensure access to all those who require it. Here trade and the existing trade agreements, including TRIPS, have a central role. Indeed, this is reflected in one of the targets linked to SDG3, which calls for better use of flexibilities granted under TRIPS to increase access to medicines:

"Provide access to affordable essential medicines and vaccines, in accordance with the Doha Declaration on the TRIPS Agreement and Public Health, which affirms the right of developing countries to use to the full the provisions in the Agreement on Trade Related Aspects of Intellectual Property Rights regarding flexibilities to protect public health, and, in particular, provide access to medicines for all."

Addressing antimicrobial resistance and maintaining drug effectiveness while increasing access will be a key challenge and require nuanced, equity sensitive policy implementation. WHO's recent reclassification of antimicrobials into "access", "watch", and "reserve" marks a step in this direction. ${ }^{32}$

Trade also affects the availability of substandard "counterfeit" antimicrobial drugs. Trade in counterfeit drugs is estimated to run into billions..$^{34}$ Availability of substandard antimicrobials is likely to undermine attempts at public regulation of antimicrobials, such as oversubscribing or the provision of antimicrobials through informal providers. Little is known about the effect of counterfeit trade in animal drugs. ${ }^{35}$ However, trade agreements and greater regulation through bodies such as the World Trade Organisation (WTO) offer solutions to this challenge.

\section{Trade agreements}

The importance of trade and intellectual property provisions to health and drug innovation is explicitly set out in target $3 \mathrm{~b}$ of SDG3. It is acknowledged as a core aspect of the Global Strategy to Fight Antimicrobial Resistance and affirmed by the political declaration resulting from the UN General Assembly special session on antimicrobial resistance in 2016. The political declaration calls on governments to: "recognise the importance of delinking the cost of investment in research and development on antimicrobial resistance from the price and volume of sales so as to facilitate equitable and affordable access to new medicines, diagnostic tools, vaccines."

This is important as some of the largest unmet needs in the research and development of new antimicrobials are found in diseases such as tuberculosis, which contribute substantially to the global antimicrobial resistance burden. ${ }^{33} \mathrm{New}$ drugs that would shorten the six month TB treatment course would alleviate the huge burden on patients and health systems and help to reduce the emergence of roughly 480000 new multidrug resistant cases each year; these are at least partly related to poor adherence to the long treatment course. ${ }^{33}$

However, research into TB treatment is not profitable enough to warrant sufficient investment from drug companies. This is reflected in the huge funding gap for TB; less than one third of the \$3.7bn for new drugs called for in the Stop TB Partnership's Global Plan to Stop TB 2011-15 was raised. Concerns extend to diagnostic tools, vaccines for disease prevention, and wider antimicrobial resistance related innovation. For example, healthcare facilities may require new types of furniture and tools with antibacterial surfaces. Such products may be an area of future innovation but need to be affordable by low and middle income countries. 


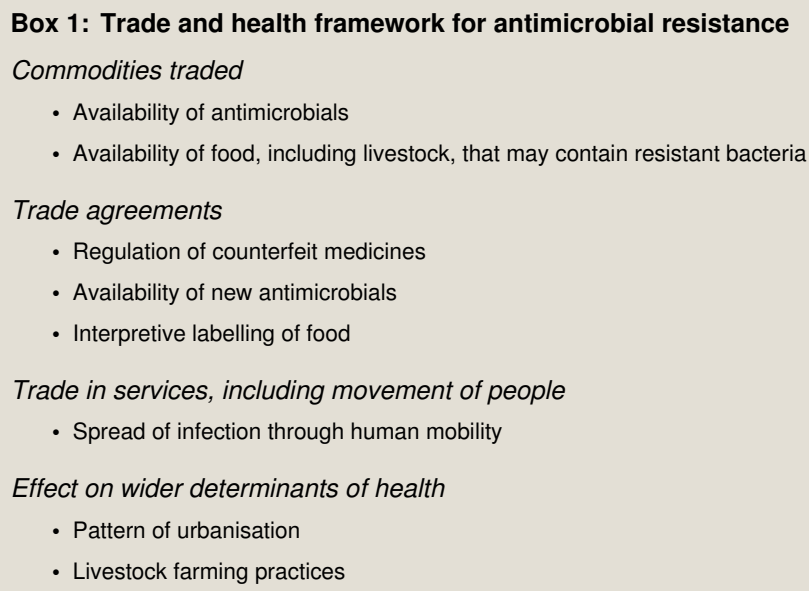

Food, animal, and plant safety in trade is regulated globally through the WTO's Sanitary and Phytosanitary Agreement. It sets out basic standards of food safety based on science, while providing some room for countries to set and retain their own regulation. A recent analysis of interpretive nutrition labelling and trade discussions under WTO regulation found that these were often at odds and there was a risk that trade agreements may constrain public health regulation. ${ }^{36}$

\section{Trade in services}

Other areas of trade and health also affect antimicrobial resistance, even though these have had less attention. Trade in services, including medical tourism, has been documented as contributing to the spread of resistant bacteria. ${ }^{41}$

\section{Wider determinants of health}

Increases in global trade and the resulting changing patterns of employment have resulted in intensive urbanisation and changes in farming. ${ }^{5}$ These in turn affect resistance in animals and its transmission. This also links closely to SDG11, which is focused on urbanisation.

\section{Discussion}

Our case study highlights the need to consider trade when seeking to tackle antimicrobial resistance and achieving the sustainable development goals. Given the close connection between food products, including food animals, and the spread of antimicrobial resistance, this seems likely to become the subject of future trade discussions and dispute-for example, if individual countries wish to introduce public health regulation that requires labelling of antibiotic use for food, or restrict imports from specific countries.

Similar public health regulations around interpretive nutrition labelling for food have led to trade discussions in the past, such as regulation surrounding fatty cuts of meat in Ghana, ${ }^{42}$ or the EU-US dispute on the use of growth hormone in cattle. ${ }^{43}$ It has yet to be established whether antimicrobial resistance could be used as a rationale for a "public health emergency" which allows for greater flexibility around intellectual property regulation under TRIPS. ${ }^{44}{ }^{43}$

\section{Regulation}

It is therefore essential that trade agreements and regulating bodies, such as the WTO and the World Intellectual Property Organisation (WIPO), consider antimicrobial resistance in the discussions on, and adjudication of disputes on, intellectual property protection. Standard setting bodies such as the Codex Alimentarius Commission and the OIE (World Organisation for Animal Health) also have an important role since WTO members are obliged to base regulations on relevant international standards. By setting stronger regulations these bodies can help tackle antimicrobial resistance and contribute to achieving the sustainable development goals.

Free trade agreements are especially important because they typically liberalise trade in agriculture to a greater extent than WTO commitments and can include more specific obligations. This relates closely to SDG16 (transparent institutions and participatory policy processes).

\section{Role of civil society, think tanks, and academic institutions}

It is important to develop international regulation and work with national regulators to prevent pitching trade against public health advocates in relation to antimicrobial resistance. ${ }^{45}{ }^{46}$ Civil society has been active in highlighting the intersection between trade and health, ranging from the HIV access movement to the recent opposition to the TTIP agreement between the EU and the US. ${ }^{47}$ Involvement of civil society, think tanks, and academic institutions is crucial for effective action on antimicrobial resistance. In Sweden, which has responded to antimicrobial resistance faster and earlier than other countries, public mobilisation and non-governmental organisations such as ReAct have been critical to placing the issue high on public and policy agenda. ${ }^{48}$ Equally, recent protest by doctors and drug sellers in Punjab, Pakistan, in response to stricter laws on substandard drugs highlight the importance of involving civil society from the outset and the need for greater public debate to improve understanding of the challenges of antimicrobial resistance.

Advances are also needed in governance mechanisms to better facilitate collaboration between health and trade, both in terms of where health convenes, as well as where health needs to engage for a better governance for health. ${ }^{25}$

These challenges throw down the gauntlet to think tanks and academic institutions to go beyond knowledge generation and dissemination. There is need to develop new ways of working on health and trade to tackle the big issues in sustainable development—such as the threat of antimicrobial resistance. The myriad ways in which trade will affect sustainable development also apply to sectors other than health. The lessons for all sectors include the need to identify interlinkages between 
sectors and goals, the importance of governance, and the need for strong and just institutions as well as inclusive processes.

Competing interests: We have read and understood BMJ policy on declaration of interests and have no relevant interests to declare.

Contributors and sources: $\mathrm{JH}$ had the idea for the paper and wrote the first draft, all other authors contributed subsequent drafts and reviewed the final version of the paper. All authors agreed the final version of the paper.

Provenance and peer review: Commissioned; externally peer reviewed. This article is one of a series commissioned by The BMJ based on an idea by the International Development Research Centre, Canada. The $B M J$ retained full editorial control over the selection of authors, external peer review, editing, and publication.

1 Jha A, Kickbusch I, Taylor P, Abbasi K. SDGs Working Group. Accelerating achievemen of the sustainable development goals. BMJ 2016;352:1409. doi:10.1136/bmj.i409 pmid: 26825535 .

2 WTO. The WTO and the sustainable development goals. 2017. https://www.wto.org/ english/thewto_e/coher_e/sdgs_e/sdgs_e.htm.

3 Sugden R, Kelly R, Davies S. Combatting antimicrobial resistance globally. Nat Microbio 2016;1:16187. doi:10.1038/nmicrobiol.2016.187 pmid:27670123.

4 Smith RD, Lee K, Drager N. Trade and health: an agenda for action. Lance 2009;373:768-73. doi:10.1016/S0140-6736(08)61780-8 pmid:19167056.

5 Hanefeld J. Globalisation and health. McGraw Hill, 2015.

6 Stiglitz JE. Trade agreements and health in developing countries. Lancet 2009;373:363-5 doi:10.1016/S0140-6736(08)61772-9 pmid:19167055.

7 Gleeson D, Friel S. Emerging threats to public health from regional trade agreements. Lancet 2013;381:1507-9. doi:10.1016/S0140-6736(13)60312-8 pmid:23453142.

8 McNeill D, Birkbeck CD, Fukuda-Parr S, Grover A, Schrecker T, Stuckler D. Political origins of health inequities: trade and investment agreements. Lancet 2017;389:760-2. doi:10.1016/S0140-6736(16)31013-3 pmid:27832871.

9 McGrady B. Trade liberalisation and tobacco control: moving from a policy of exclusion towards a more comprehensive policy. Tob Control 2007:16:280-3. doi:10.1136/tc.2006. 019141 pmid:17652245

10 Hanefeld J, Hawkins B, Knai C, Hofman K, Petticrew M. What the InBev merger means for health in Africa. BMJ Glob Health 2016;1:e000099. doi:10.1136/bmjgh-2016000099 pmid:28588945.

11 Clark SE, Hawkes C, Murphy SM, Hansen-Kuhn KA, Wallinga D. Exporting obesity: US farm and trade policy and the transformation of the Mexican consumer food environment. Int J Occup Environ Health 2012;18:53-65. doi:10.1179/1077352512Z.0000000007 pmid: 22550697.

12 Arroyo P, Loria A. The Mexican epidemic of obesity and the North American Free Trade Agreement. Int J Occup Environ Health 2012;18:348, author reply 348.pmid:23433297.

13 Hawkes C, Chopra M, Friel S. Globalization, trade and the nutrition transition. In: Labonte R, Schrecker T, Packer C, Runnels V, eds. Globalization and health: pathways, evidence and policy. Routledge, 2009: 235-62, https://pdfs.semanticscholar.org/d7b1/ 3af442586d26946fb3f55aa86a25d7535784.pdf

14 Aginam O. Global health governance, intellectual property and access to essential medicines: opportunities and impediments for south-south cooperation. Global Health Govern, 2010.

15 Hoen E, Berger J, Calmy A, Moon S. Driving a decade of change: HIV/AIDS, patents and access to medicines for all. J Int AIDS Soc 2011;14:15. doi:10.1186/1758-2652-14-15 pmid: 21439089.

16 Gray A, Vawda Y. TRIPS, access to medicines and local production in South Africa. In: Loefgren $\mathrm{H}$, Williams OD, eds. The new political economy of pharmaceuticals. Palgrave Macmillian, 2013doi:10.1057/9781137315854 10.

17 Gleeson D, Friel S. Emerging threats to public health from regional trade agreements Lancet 2013;381:1507-9. doi:10.1016/S0140-6736(13)60312-8 pmid:23453142.

18 Friel S, Gleeson D, Thow AM, et al. A new generation of trade policy: potential risks to diet-related health from the trans pacific partnership agreement. Global Health 2013;9:46. doi:10.1186/1744-8603-9-46 pmid:24131595.

19 Gleeson DH, Tienhaara KS, Faunce TA. Challenges to Australia's national health policy from trade and investment agreements. Med J Aust 2012;196:354-6. doi:10.5694/mja11 . 11635 pmid:22432677.

20 Thow AM, Snowdon W, Labonté R, et al. Will the next generation of preferential trade and investment agreements undermine prevention of noncommunicable diseases? A prospective policy analysis of the Trans Pacific Partnership Agreement. Health Policy 2015;119:88-96. doi:10.1016/.jhealthpol.2014.08.002 pmid:25217839.

21 Smith RD, Chanda R, Tangcharoensathien V. Trade in health-related services. Lancet 2009:373:593-601. doi:10.1016/S0140-6736(08)61778-X pmid:19167053.

22 Noree T, Hanefeld J, Smith R. Medical tourism in Thailand: a cross-sectional study. Bull World Health Organ 2016;94:30-6. doi:10.2471/BLT.14.152165 pmid:26769994.
23 Saliba V, Legido-Quigley H, Hallik R, Aaviksoo A, Car J, McKee M. Telemedicine across borders: a systematic review of factors that hinder or support implementation. Int $J \mathrm{Med}$ Inform 2012;81:793-809. doi:10.1016/j.jmedinf.2012.08.003 pmid:22975018.

24 Hanefeld J, Horsfall D, Lunt N, Smith R. Medical tourism: a cost or benefit to the NHS?PLOS One 2013;8:e70406. doi:10.1371/journal.pone.0070406 pmid:24204556.

25 Ottersen OP, Dasgupta J, Blouin C, et al. The political origins of health inequity: prospects for change. Lancet 2014:383:630-67. doi:10.1016/S0140-6736(13)62407-1 pmid:24524782.

26 Labonté R, Schrecker T. Globalization and social determinants of health: Promoting health equity in global governance (part 3 of 3). Global Health 2007;3:7. doi:10.1186/1744-86033-7 pmid: 17578570

27 Labonté $\mathrm{R}$, Mohindra K, Schrecker $\mathrm{T}$. The growing impact of globalization for health and public health practice. Annu Rev Public Health 2011;32:263-83. doi:10.1146/annurevpublhealth-031210-101225 pmid:21219153.

28 O'Neill A. Review on antimicrobial resistance, tackling drug resistant infections globally. Infection prevention, control and surveillance: limiting the development and spread of drug resistance. Wellcome Trust, HM Government, 2016.

29 Rittel H, Webber MM. 2.3 planning problems are wicked. Polity 1973;4:155-69.

30 Holmes AH, Moore LS, Sundsfjord A, et al. Understanding the mechanisms and drivers of antimicrobial resistance. Lancet 2016;387:176-87. doi:10.1016/S0140-6736(15)004730 pmid:26603922.

31 Laxminarayan R, Matsoso P, Pant S, et al. Access to effective antimicrobials: a worldwide challenge. Lancet 2016;387:168-75. doi:10.1016/S0140-6736(15)00474-2 pmid:26603918.

32 McCarthy M. What makes an essential medicine? WHO's new list focuses on antibiotic resistance, adds expensive drugs, and downgrades Tamiflu. BMJ 2017;358:j3044. doi: 10.1136/bmj.j3044 pmid:28687536

33 WHO. Global tuberculosis report 2016. WHO, 2016.

34 Mackey TK, Liang BA. The global counterfeit drug trade: patient safety and public health risks. J Pharm Sci 2011;100:4571-9. doi:10.1002/jps.22679 pmid:21698604.

35 Mshana SE, Matee M, Rweyemamu M. Antimicrobial resistance in human and anima pathogens in Zambia, Democratic Republic of Congo, Mozambique and Tanzania: an urgent need of a sustainable surveillance system. Ann Clin Microbiol Antimicrob 2013;12:28. doi:10.1186/1476-0711-12-28 pmid:24119299.

36 Thow AM, Jones A, Hawkes C, Ali I, Labonté R. Nutrition labelling is a trade policy issue: lessons from an analysis of specific trade concerns at the World Trade Organization. Health Promot Int 2017; daw109.[Epub ahead of print.] doi:10.1093/heapro/daw109 pmid: 28082373.

37 US Department of Agriculture. Livestock and poultry: world markets and trade. USDA, 2017.

38 Alexander TW, Inglis GD, Yanke LJ, et al. Farm-to-fork characterization of Escherichia coli associated with feedlot cattle with a known history of antimicrobial use. Int $J$ Food Microbiol 2010;137:40-8. doi:10.1016/j.ijfoodmicro.2009.11.008 pmid:19963297.

39 de Boer E, Zwartkruis-Nahuis JT, Wit B, et al. Prevalence of methicillin-resistant Staphylococcus aureus in meat. Int J Food Microbiol 2009;134:52-6. doi:10.1016/j. ijfoodmicro.2008.12.007 pmid:19144432.

40 Founou LL, Founou RC, Essack SY. Antibiotic resistance in the food chain: A developing country-perspective. Front Microbiol 2016;7:1881. doi:10.3389/fmicb.2016.01881 pmid: 27933044.

41 Kumarasamy KK, Toleman MA, Walsh TR, et al. Emergence of a new antibiotic resistance mechanism in India, Pakistan, and the UK: a molecular, biological, and epidemiological study. Lancet Infect Dis 2010:10:597-602. doi:10.1016/S1473-3099(10)70143-2 pmid: 20705517.

42 Thow AM, Annan R, Mensah L, Chowdhury SN. Development, implementation and outcome of standards to restrict fatty meat in the food supply and prevent NCDs: learning from an innovative trade/food policy in Ghana. BMC Public Health 2014;14:249. doi:10. 1186/1471-2458-14-249 pmid:24625217.

43 Bureau J-C, Marette S, Schiavina A. Non-tariff trade barriers and consumers' information: The case of the EU-US trade dispute over beef. Eur Rev Agric Econ 1998;25:437-62doi: 10.1093/erae/25.4.437.

44 Rassy D, Smith RD. The economic impact of H1N1 on Mexico's tourist and pork sectors. Health Econ 2013;22:824-34. doi:10.1002/hec.2862 pmid:23744805.

45 Walls HL, Smith RD, Drahos P. Improving regulatory capacity to manage risks associated with trade agreements. Global Health 2015;11:14. doi:10.1186/s12992-015-0099-7 pmid: 25890343.

46 Thaiprayoon S, Smith R. Capacity building for global health diplomacy: Thailand's experience of trade and health. Health Policy Plan 2015;30:1118-28. doi:10.1093/heapol/ czu117 pmid:25339636.

47 Jarman $\mathrm{H}$. Public health and the Transatlantic trade and investment partnership. Eur J Public Health 2014;24:181. doi:10.1093/eurpub/ckt201 pmid:24671629.

48 Swedish Government. Sweden and the 2030 Agenda—report to the UN High Level Political Forum 2017 on sustainable development. Swedish Government, 2017.

Published by the BMJ Publishing Group Limited. For permission to use (where not already granted under a licence) please go to http://group.bmj.com/group/rights-licensing/ permissions

This is an Open Access article distributed in accordance with the Creative Commons Attribution Non Commercial (CC BY-NC 4.0) license, which permits others to distribute, remix, adapt, build upon this work non-commercially, and license their derivative works on different terms, provided the original work is properly cited and the use is non-commercial. See: http://creativecommons.org/licenses/by-nc/4.0/. 


\section{Key messages}

Antimicrobial resistance shows how trade can affect health and the sustainable development goals Trade and its intersection with health is critical to achieving sustainable development, yet it is little understood

Civil society, including think tanks, and academic institutions have a key role in exploring and acting on the intersection between trade and health 